\title{
Miscellanea
}

\section{The American Charm}

\author{
K D Gupta \\ Emeritus Professor (Late), Department of Medicine, S P Medical College and Associated Group of \\ Hospitals, Bikaner, Rajasthan, India
}

Four years back in a global polling most of the students opted for training in America; England rated next and Germany the last. It is interesting how "Old order changeth yielding place to new." One shall recall famous Dr. Johonson advising Arthur lee to have training in England because "The scotch or any foreign education is like a house build to last a man's life time, the English is like a palace or fortress intended to last for many ages. The first build lightly, the last lay a very strong and firm foundation before they begin work". What is the charm in America which leads Johonson to point across the Atlantic rather than the Highlands? Is this charm real or fictitious? Truth perhaps lies in Keat's words "Heard melodies are sweet, but those unheard sweeter."

Before starting for America I chanced to read a pamphlet. The first sentence in it described America as the land which has been created with the best agreement between Nature and God. "The land of honey and milk, "The promised land" leads one to expect "No sleep till morn when youth and pleasure meet". My readers would be interested in knowing the life of a medical student in this country and this share in the exploit of the "American charm".

King Charles II once said "He was no atheist, but he could not think if God would make a man miserable only for taking a little pleasure out of the way". Every student in this country believes in this, yet so hard pressed for time are they, that seldom they have a pleasure out of the way. A medical student has become over-worked universally, and reproduced below are the type of talks which one often hears in their dining rooms, or in the leisure hours over a cup of coffee. One group talks of:

"Cinchophen will check the gout Septic tonsils should come out. Fractured femurs must be pinned. Charcoal biscuits break the wind."

And the other group:

"A.C. T.H. comes from whales

Schistostmas spread by snails
Fatty stools are found in sprue

And in celiac children too."

Yet "All is well that ends well". Most of them get through the medical school in the minimum time. The pass percentage is over 90. A student is examined throughout the year and in the final assessment all the previous record is taken into consideration.

There is, inspite of all this, a general feeling of restlessness. The basic problem has been that the medical schools have directly or indirectly encouraged students to concentrate or limit too narrowly their college studies to scientific fields. This one sided technology blinds them towards many more important things in life an appreciation of art, a taste to change the curriculum but as one of the frustrated Deans once remarked "It is easier of remove a cemetry then to change a curriculum".

Surprisingly, in most places little facilities exist for the physical development of medical students. After pouring over their books which in words are the bloodless substitute for life the students diverts himself with a television set, a radio, a movie or going to a community dance. His plight has been fairly summarized by a commentator when he said "With ears, eyes and mouth open the American medical student staggers under the torrent of sense impressions directed on him, as from pressure hoses, by his teachers". The commentator forgot that a medical student has also to keep his nose open and his skin intact to be able to appreciate odour and touch.

It may sound one side. If 50 percent of them are married when they leave the medical school there must certainly be some lighter side of the picture. It sure is. But it is rarely for the "Endearing elegance of female friendship" or for the "Sweeter sounds of Woman's praise". He must have been a very observant poet who wrote about the stethoscope of a medical student and the variegated uses to which he employs it: "One leaves a silken handkerchief Another leaves a glove 
That these may serve as slender chains

To solder sundered love

But I, my stethoscope resign

When fortune bids us part

That it may catch your lightest breath

The message of your heart".

Invariably, however, the Lubh carried by the stethoscope ends in church bells, and these wives whom they acquire early in their life earn money for them to help them through their costly medical education.

The medical student is respected both by the public and the patients, and he bears himself with dignity. It is like a horse who keeps his neck high because it senses that a king is riding it, and not the trot of a crow in the peacock's features. The spirit of discussion is encouraged amongst students and the fascination of a name does not lead to surrender of judgement hoodwinked.

Talking of logic I am reminded of a clinical examination here. The examiner caught a student fumbling a tumor with his left hand. On being asked why did he not use the right hand? The student explained that he was left handed.
The examiner angrily asked the nearby student who was doing the same "Are you also by any means left handed Mr. X." The student politely answered, "I am ambidextrous, Sir."

During their vacation they have different life. Most of them cast the books away and go as guides to children's camps or to Europe, or take to work in a factory or oven to manual labour. An average student earns from 500 to 700 dollars in their vacation.

An average American student may perhaps be more happy and may even fare better because he is exposed to a better organized system, a system which, however, is still in an experimental stage. Any how he has more opportunities or leisure and pleasure. Potentially an Indian student is as good as anywhere in the world. His inherent qualities of tenaciousness, sense of duty, and proper perspective on pleasure would stand him well if he turned round and talked like the Tower of England to Tower of Pisa "If you have inclination, I have the time".

\section{Corresponding Author}

email:rajeevgg@gmail.com 